\title{
Presence of Mycobacterium leprae genotype 4 in environmental waters in Northeast Brazil
}

\author{
Maísa Viana de Holanda ${ }^{[1]}$, Livia Erika Carlos Marques ${ }^{[1]}$, Maria Luisa Bezerra de Macedo ${ }^{[1]}$, \\ Maria Araci de Andrade Pontes ${ }^{[2]}$, José Antonio Beltrão Sabadia ${ }^{[3]}$, \\ Ligia Regina Franco Sansigolo Kerr ${ }^{[4]}$, Rosa Lívia Freitas Almeida ${ }^{[5]}$ \\ and Cristiane Cunha Frota ${ }^{[1]}$
}

\begin{abstract}
[1]. Departamento de Patologia e Medicina Legal, Faculdade de Medicina, Universidade Federal do Ceará, Fortaleza, CE, Brasil. [2]. Centro Dermatológico Dona Libânia, Fortaleza, CE, Brasil. [3]. Departamento de Geologia, Universidade Federal do Ceará, Fortaleza, CE, Brasil. [4]. Departamento de Saúde Comunitária, Faculdade de Medicina, Universidade Federal do Ceará, Fortaleza, CE, Brasil. [5]. Programa de Pós-Graduação em Saúde Coletiva, Universidade de Fortaleza, Fortaleza, CE, Brasil.
\end{abstract}

\begin{abstract}
Introduction: This study quantified Mycobacterium leprae bacilli in environmental water samples from five municipalities in the State of Ceará by quantitative polymerase chain reaction (qPCR) and compared the identified genotypes with those obtained from leprosy patient biopsies. Methods: We collected five replicas from each of the 30 selected reservoirs and skin lesion biopsies from 25 new leprosy cases treated at a reference center in Fortaleza, Ceará from 2010 to 2013. The 16S rRNA gene region of $M$. leprae was amplified by qPCR and a standard curve was created with the pIDTBlue 16SrRNAMlep plasmid. The Juazeiro do Norte water samples and the biopsies were genotyped (single nucleotide polymorphism [SNP] 1 to 4) and the SNP 4 genotypes were subtyped. Results: Of the 149 water samples analyzed, $54.4 \%$ were positive for the M. leprae DNA. The M. leprae bacilli copy number ranged from $1.42 \times 10^{-1}$ to $1.44 \times 10^{+2}$. Most biopsies showed SNP type $4(64 \%)$, while all samples from Juazeiro do Norte were SNP type 4, with subtype 4-N appearing at the highest frequency. Conclusions: We suggest that environmental waters containing $M$. leprae bacilli play an important role in disease transmission, justifying PGL-1 seropositivity in individuals living in areas where there is no reported case, and in leprosy cases individuals who report no previous contact with other case. Therefore, further investigation is needed to clarify disease transmission in this region and to explore the role of the environment. We also suggest that in this area surveillance for leprosy cases should be intensified.
\end{abstract}

Keywords: Mycobacterium leprae. Leprosy. Real-time polymerase chain reaction. Water. Biopsy.

\section{INTRODUCTION}

Leprosy is a chronic granulomatous infectious disease that primarily affects the skin and peripheral nerves, leading to nerve function impairments. The causative agent of leprosy, Mycobacterium leprae, is an obligatory intracellular bacterium, not cultivable in axenic media. Comparative analysis of the genomes of M. leprae strains has demonstrated that the disease originated in East Africa with subsequent migration to occidental Africa and the Americas ${ }^{1}$.

In $2014,213,899$ new cases of leprosy were detected worldwide, distributed in 121 countries $^{2}$; in that same year, 31,064 cases, $14.5 \%$ of the world's total, were detected in Brazil. A small number of countries account for approximately $90 \%$ of

Corresponding author: Dra. Cristiane Cunha Frota.

e-mail: cristianefrota71@gmail.com

Received 13 October 2016

Accepted 23 March 2017 all leprosy cases detected worldwide, including India, Brazil, Indonesia, Ethiopia, Bangladesh, The Democratic Republic of the Congo, and $\mathrm{Nepal}^{3}$. In the State of Ceará, located in Northeastern Brazil, leprosy is considered endemic, with a reported new leprosy case detection rate (CDR) of 23.7/100,000 inhabitants in 2014. In the same year, the occurrence of the disease in children under 15 years in Ceará was 6.1/100,000 inhabitants, demonstrating the existence of active disease transmission foci ${ }^{4}$. In 2015 , the state reported new leprosy cases in $148(80.5 \%)$ municipalities; 18 of these had a CDR $>40.0$ and were considered hyperendemic.

The main means of leprosy transmission occurs through prolonged and continuous person-to-person contact. The existence of clinical disease cases in which patients did not report being in contact with other patients, suggests human infection from environmental sources ${ }^{5,6}$. A study conducted by Desikan and Sreevatsa ${ }^{7}$ demonstrated the viability of M. leprae outside the human body under several unfavorable environmental conditions. In addition, the presence of $M$. leprae in water $^{8}$, soil from villages where the disease is endemic ${ }^{9}$, 
and in the soil from the peridomicile of patients have also been reported ${ }^{10}$. Similarly, the viability of the bacillus within protozoan Acanthamoeba spp. has also been demonstrated ${ }^{11}$. The environment has been proposed as a reservoir allowing the bacillus to remain infectious following long periods outside the human body and consequent continual contamination and transmission of the disease ${ }^{6}$.

In this study, we detected and quantified the presence of M. leprae deoxyribonucleic acid (DNA) in environmental water samples obtained from five municipalities in the State of Ceará by quantitative polymearase chain reaction (qPCR). In addition, we compared the environmental water genotypes with those of clinical samples from leprosy cases. Bacilli shed by the untreated leprosy cases in environmental waters, if remains viable then it could possibly have implications in transmission of the disease contributing to its prevalence. Therefore, surveillance implementation of these waters harboring the $M$. leprae, lead to prevent potential new cases and implementation of early detection. In this way, implementation of public health programs with new intervention strategies to prevent leprosy cases are urgent needed.

\section{METHODS}

\section{Study setting}

This study was conducted from November 2010 to December 2013. The municipalities were selected according to the epidemiological characteristics of leprosy (hyper, high, medium, and low endemicity), as well as geological and climatic conditions. The studied water sources are located in the following municipalities of the State of Ceará: Boa Viagem, Crato, Juazeiro do Norte, Mulungu, and Sobral, with average temperatures ranging from 24 to $29^{\circ} \mathrm{C}$. These municipalities are located $217,567,491,117$, and $240 \mathrm{~km}$, respectively, from the state capital. The municipalities of Juazeiro do Norte, Sobral, and Crato were considered hyperendemic in 2012, with CDRs of 114, 91 and 53, respectively ${ }^{12}$. In contrast, the City of Boa Viagem reported only nine new cases in the same year, while no cases were reported in Mulungu ${ }^{12}$.

Water samples were collected from natural sources, such as ponds, rivers, streams, recreational habitats, and wells. The sampling points were designated by the local health agents and were chosen based on their use by the local population for recreational and/or household purposes (drinking, bathing, washing dishes and clothing, and animals, including livestock, domestic and wild animals). Samples were collected from five sites in Juazeiro do Norte, eight sites in Sobral, four sites in Crato, seven sites in Boa Viagem, and six sites in Mulungu.

\section{Collection of water samples}

At each site, five replicates were collected at different depths, designated by the letters $A$ to $E$. The collected samples were identified by the initial of the municipality [Boa Viagem (B); Crato (C); Juazeiro do Norte (J); Mulungu (M) and Sobral (S)] in numerical order (B1 to B7; $\mathrm{C} 1$ to $\mathrm{C} 4$; $\mathrm{J} 1$ to $\mathrm{J} 5$; $\mathrm{M} 1$ to $\mathrm{M} 6$; and $\mathrm{S} 1$ to $\mathrm{S} 8$ ) and the replicates were assigned in alphabetical order (B1a, B1b, B1c, B1d, B1e, B2a ... B7e). The $A$ sample was collected from the surface of the reservoir, while the $B, C$, and $D$ samples were from an intermediate depth and the $E$ sample was from the bottom of the reservoir. During transport of samples to the laboratory in Fortaleza, a sample from Boa Viagem (B7d) was damaged. All water samples were conditioned in sterile amber bottles with a 1,000-mL capacity, totaling 149 environmental water samples. The samples were transported within 24 hours of sampling in styrofoam boxes containing ice cubes to the mycobacteria laboratory of the Federal University of Ceará, in Fortaleza, Ceará State.

\section{Biopsy samples}

Biopsies were collected from 25 new leprosy cases prior to commencing treatment; punches $6 \mathrm{~mm}$ in diameter were removed from the edge of the skin lesions. The procedure was conducted at Dona Libânia National Reference Centre for Sanitary Dermatology (CDERM) in the City of Fortaleza, Ceará. The collected material was transferred into sterile $1.5-\mathrm{mL}$ microtubes and maintained at $-20^{\circ} \mathrm{C}$ until DNA extraction using the DNeasy Blood \& Tissue kit (Qiagen Sciences Inc, Germantown, USA).

\section{Quantitative polymerase chain reaction}

Deoxyribonucleic acid extraction from water samples was performed using the PowerWater DNA Isolation kit (Mo Bio Laboratories, Carlsbad, USA) according to the manufacturer's instructions. The obtained DNA was stored at $-20^{\circ} \mathrm{C}$. qPCR reactions were conducted using an ESCO 96 Spectrum Real Time Thermal Cycler (Esco Micro Pte Ltd, Changi, Singapore) with primers 16S3-Forward: 5' - TCG AAC GGA AAG GTC TCT AAA - 3' and 16S3-Reverse: 5' - CTT TCC ACC ACA AGA CAT GC - 3' that amplify a region of the ribosomal RNA gene specific to M. leprae.

Absolute quantification by qPCR was conducted using the SYBR Green PCR kit Power Master Mix (Applied Biosystems Inc, Foster City, USA); each individual reaction consisted of $12.5 \mu \mathrm{L}$ Master Mix, $1 \mu \mathrm{L}$ of each primer, $5.5 \mu \mathrm{L}$ ultra-pure water, and $5 \mu \mathrm{L}$ of DNA from the environmental sample (total volume of $25 \mu \mathrm{L}$ ). The reaction conditions were as follows: initial denaturation at $95^{\circ} \mathrm{C}$ for 10 minutes; followed by 45 cycles of denaturation at $94^{\circ} \mathrm{C}$ for 30 seconds, annealing at $55^{\circ} \mathrm{C}$ for 30 seconds, and extension at $72^{\circ} \mathrm{C}$ for 30 seconds; followed by a final extension at $72^{\circ} \mathrm{C}$ for 10 minutes. M. leprae copy numbers were calculated by absolute quantification using a standard curve for each run. To evaluate the Cycle Threshold $\left(\mathrm{C}_{\mathrm{t}}\right)$, the obtained data were analyzed using the Swift Spectrum Real Time Software 96 (Esco Micro Pte Ltd, Changi, Singapore).

The standard curve was generated using a ten-fold dilution series (ranging from 10 to $10^{9}$ copies/reaction) of plasmid pIDTBlue16SrRNAMleprae (Integrated DNA Technologies, Inc., San Diego, USA), which contains a 171-bp fragment of the M. leprae 16S ribosomal ribonucleic acid (rRNA) gene $^{10}$. Other mycobacteria species and non-mycobacterial (Mycobacterium tuberculosis H37Rv, Mycobacterium sp., Streptococcus pneumoniae ATCC 49619, Staphylococcus aureus, and Escherichia coli) were also included as controls. These strains were obtained from the bacterial culture collection 
of the Mycobacterial Laboratory of the Federal University of Ceará, Fortaleza, Ceará and the DNA samples were adjusted to $10 \mu \mathrm{g} / \mathrm{mL}$ prior to being used for qPCR.

\section{Genotyping of Mycobacterium leprae isolates}

qPCR-positive samples were subjected to single-nucleotide polymorphism identification (SNPs 1 to 4), using two pairs of primers targeting nucleotides at positions 14676 and 2935685 of the M. leprae genome ${ }^{1,13}$. The Taq PCR Master Mix kit (Qiagen Sciences Inc, Germantown, USA) was used for amplification with the following conditions: $94^{\circ} \mathrm{C}$ for 3 minutes; followed by 45 cycles of $94^{\circ} \mathrm{C}$ for 1 minute, $55^{\circ} \mathrm{C}$ for 1 minute, and $72^{\circ} \mathrm{C}$ for 2 minutes; with a final extension at $72^{\circ} \mathrm{C}$ for 10 minutes ${ }^{14}$. Following amplification of the 2935685 genomic fragments, samples were subjected to enzymatic digestion with $10 \mathrm{U} / \mu \mathrm{L}$ of Bst UI (New England Biolabs, Ipswich, USA) at $60^{\circ} \mathrm{C}$ for 1 hour. While the PCR products of the 14676 region were digested with $10 \mathrm{U} / \mu \mathrm{L}$ of $S m l \mathrm{I}$ at $55^{\circ} \mathrm{C}$ for 1 hour.

The samples identified as genotype 4 were subjected to subtyping, from 4-N, 4-O, to 4- $\mathrm{P}^{14}$. The amplification reactions were performed with the Taq PCR Master Mix kit (Qiagen Sciences Inc, Germantown, USA), using $1.5 \mu \mathrm{L}$ of primers Ins-978589-F, Ins-9789589-R, Del-1476519-F, and Del$1476519-\mathrm{R}^{14}$

\section{Statistical analysis}

Graphics and descriptive tables (means, standard deviation, and proportions) were used to present the data (DNA positivity, $\mathrm{Ct}$, and copy number). Bacilli copy number range in the water samples and SNP typing were compared by chi-square and Fisher's exact two-tailed tests. Crude and adjusted Poisson regression models with robust variance and estimated incidence rate ratios (IRR) and 95\% confidence intervals (95\% CI) were generated to assess the associations between M. leprae genotyping positivity (water and biopsy samples) and genotype (SNP typing 1 or 2, 3, and 4). The level of significance was $p$ $<0.05$. STATA statistical software version 13.1 was used for the analyses.

\section{Ethics considerations}

All patients were aware and gave written informed consent for the collections of biopsy samples. The study was approved by CDERM Ethical Committee (protocol 011/07) and performed in compliance with the guidelines of the Ethical Committee.

\section{RESULTS}

Of the 149 analyzed water samples from the five municipalities surveyed, 81 (54.4\%) were positive for M. leprae DNA (Table 1). The municipality of Mulungu had DNA positivity in 22 of the 30 M1 to M6 replicates (73.3\%). Juazeiro do Norte had 16 positive samples out of $25(64 \%)$ for sampling points $\mathrm{J} 1, \mathrm{~J} 2, \mathrm{~J} 3 \mathrm{~J} 4$ and J5. The town of Boa Viagem had 19 positive samples out of 34 (55.9\%), only collection point B7 (dam) was negative. The municipality of Sobral, with the greatest number of collected samples (40 replicates), had $18(45 \%)$ replicates positive for M. leprae (points S1, S2, S4, S5, S6, S7, and S8). The Sobral samples collected in site S3 (lake) were negative.

\section{TABLE 1}

Mycobacterium leprae 16S rRNA gene DNA positivity in environmental water reservoirs from the municipalities of Boa Viagem, Crato, Mulungu, Juazeiro do Norte, and Sobral, Ceará, Brazil, 2010-2013 determined by qPCR.

\begin{tabular}{|c|c|c|}
\hline Municipality & Type of reservoir & $\begin{array}{c}\text { Dna Positivity } \\
\text { n (\%) }\end{array}$ \\
\hline Boa Viagem $(\mathrm{N}=34)$ & & $19(55.9)$ \\
\hline B 1 & Dam & 5 \\
\hline B 2 & Dam & 2 \\
\hline B 3 & Dam & 3 \\
\hline B 4 & Dam & 3 \\
\hline B 5 & Dam & 2 \\
\hline B 6 & Dam & 4 \\
\hline B 7 & Dam & 0 \\
\hline Crato $(\mathrm{N}=20)$ & & $6(30.0)$ \\
\hline $\mathrm{C} 1$ & Recreational stream & 4 \\
\hline $\mathrm{C} 2$ & Dam & 2 \\
\hline C 3 & Dam & 0 \\
\hline $\mathrm{C} 4$ & Dam & 0 \\
\hline Mulungu $(\mathrm{N}=30)$ & & $22(73.3)$ \\
\hline M 1 & Lake & 5 \\
\hline M 2 & Recreational stream & 3 \\
\hline M 3 & Well & 4 \\
\hline M 4 & Well & 5 \\
\hline M 5 & Stream & 3 \\
\hline M 6 & Well & 2 \\
\hline Juazeiro do Norte $(\mathrm{N}=25)$ & & $16(64.0)$ \\
\hline $\mathrm{J} 1$ & Dam & 5 \\
\hline $\mathrm{J} 2$ & Dam & 3 \\
\hline $\mathrm{J} 3$ & Dam & 4 \\
\hline $\mathrm{J} 4$ & Dam & 3 \\
\hline $\mathrm{J} 5$ & Stream & 1 \\
\hline Sobral (N=40) & & $18(45.0)$ \\
\hline S 1 & Dam & 4 \\
\hline S 2 & Dam & 3 \\
\hline S 3 & Lake & 0 \\
\hline S 4 & River & 2 \\
\hline S 5 & River & 1 \\
\hline S 6 & Stream & 3 \\
\hline S 7 & River & 3 \\
\hline S 8 & River & 2 \\
\hline Total & & $81(54.4)$ \\
\hline
\end{tabular}

rRNA: ribosomal ribonucleic acid; DNA: deoxyribonucleic acid; qPCR: quantitative polymerase chain reaction.

The lowest positivity was detected in the municipality of Crato; 6 of the 20 collected replicates (30\%) from sampling points $\mathrm{C} 1$ (recreational stream) and C2 (dam) were positive.

A 10-fg dilution of plasmid pIDT16SrRNAMleprae was defined as the analytical sensitivity or detection limit for the qPCR assay, showing a Ct value $<37$ cycles in every standard 
curve run. Titration of plasmid pIDT16SrRNAMleprae using 16S rRNA primers revealed a limit of detection of approximately 30 cells, based on a $M$. leprae chromosome size of $\sim 3.27 \mathrm{Mb}$.

To determine the specificity of the qPCR assay, two other mycobacterial species and three other bacterial species and control samples were also tested. The target region was only amplified by qPCR from mycobacteria species and with M. leprae DNA; however, the amplicons were obtained using a different $\operatorname{Tm}\left(77.5^{\circ} \mathrm{C}\right)$ compared to that for M. leprae $\left(78.1^{\circ} \mathrm{C}\right)$. No DNA amplification was observed for bacterial species from other genera or the controls. The obtained standard curve (Figure 1) was linear with a Pearson correlation coefficient (r) of -0.996 , a correlation coefficient $\left(\mathrm{R}^{2}\right)$ of 0.992 , and an amplification efficiency of $99.51 \%$. Table 2 details the average $\mathrm{C}_{t}$ of the environmental water samples from each municipality, as well as the copy number range. The municipality of Mulungu showed the highest average $\mathrm{C}_{\mathrm{t}}(29.55 ; 27.8$ to 34.9 range $)$; followed by Crato $(29.48 ; 25.5$ to 33.4 range) and Juazeiro do Norte average (28.96; 28.0 to 30.1 range). Lower $\mathrm{C}_{t} \mathrm{~s}$ were found in the water samples from Sobral (average $\mathrm{C}_{t}$ of 28.8) and Boa Viagem (average $\mathrm{C}_{t}$ of 27.4).

Of the 25 patient biopsy samples analyzed, six (24\%) samples were characterized as SNP 1 or 2 , three $(12 \%)$ samples were SNP genotype 3, and 16 (64\%) samples were classified as SNP 4 (Figure 2).

As expected, the Poisson regression model, based on crude and adjusted analysis, demonstrated that the positivity incidence rate ratio in the biopsy samples was $60 \%$ higher than that in the water samples ( $p=0.0016$; Table 3). No statistical difference in $M$. leprae genotyping was observed among biopsy and water samples from Juazeiro do Norte $(p=1,000)$. The majority of biopsy and water samples were characterized as SNP 4-N, with $16(100 \%)$ and $14(87.5 \%)$ samples, respectively. The other two water samples $(2 / 16,12.5 \%)$ were identified as SNP 4-O.

\section{DISCUSSION}

The results of this study demonstrate high M. leprae DNA positivity in environmental waters. In addition, it reveals that the M. leprae genotype present in the collected water samples is the same as that found in the lesions of leprosy patients. Previous studies with environmental samples have also shown the presence of $M$. leprae DNA with varying positivity percentages: from 24 to $47.7 \%$ in water ${ }^{8,15} ; 33.3 \%, 34.3 \%$, and $37.5 \%$ in soil samples from the peridomicile of leprosy patients ${ }^{9,10,16}$; and $21 \%$ in armadillos from endemic regions in Ceará ${ }^{17}$.

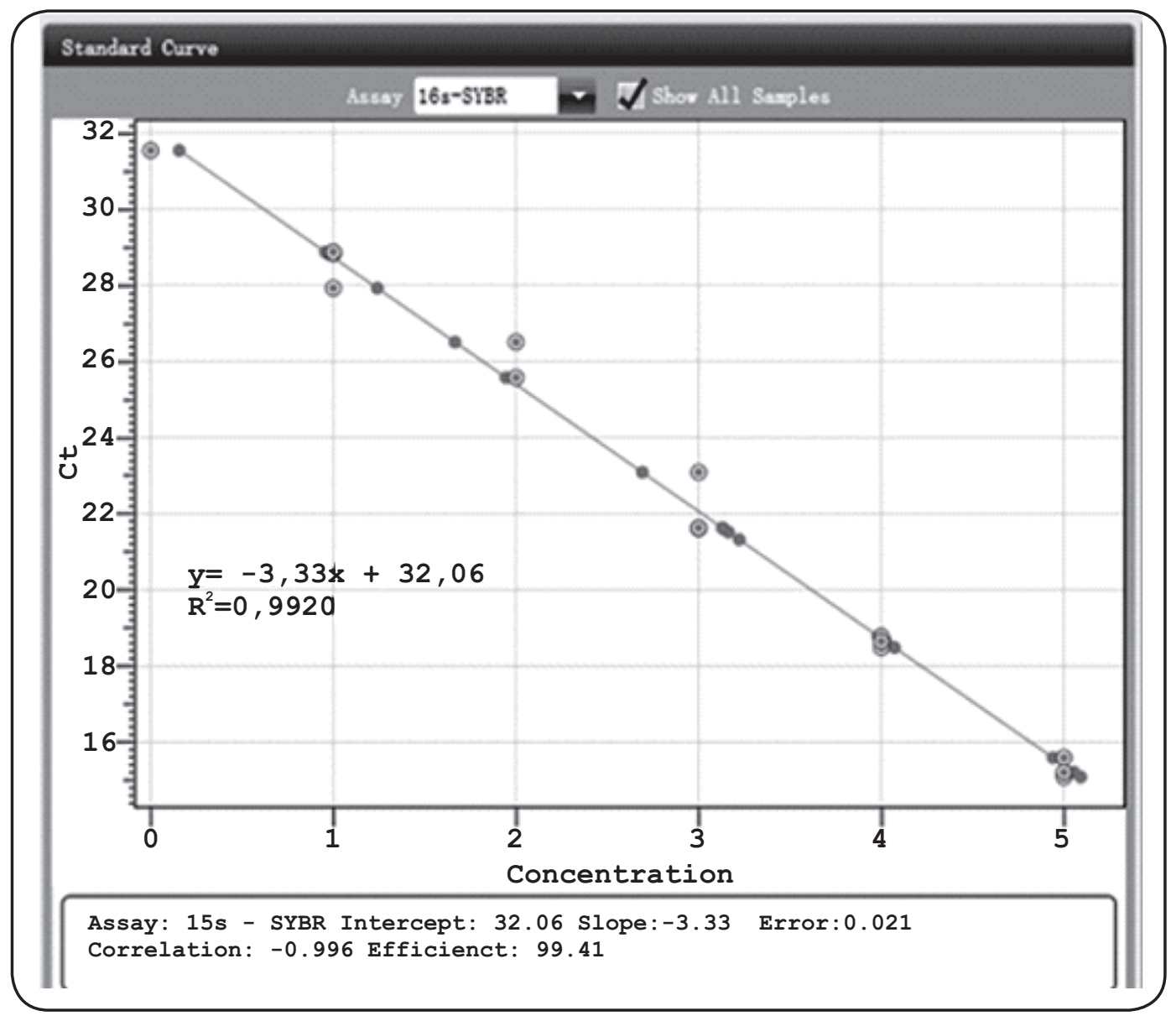

FIGURE 1 - Linear regression of the Cycle Threshold values vs. Mycobacterium leprae plasmid DNA dilutions, 2010-2013. DNA: deoxyribonucleic acid; Ct: cycle threshold; y: theoretical limit of detection of the reaction (Ct value); $\mathbf{R}^{2}$ : correlation coefficient. 


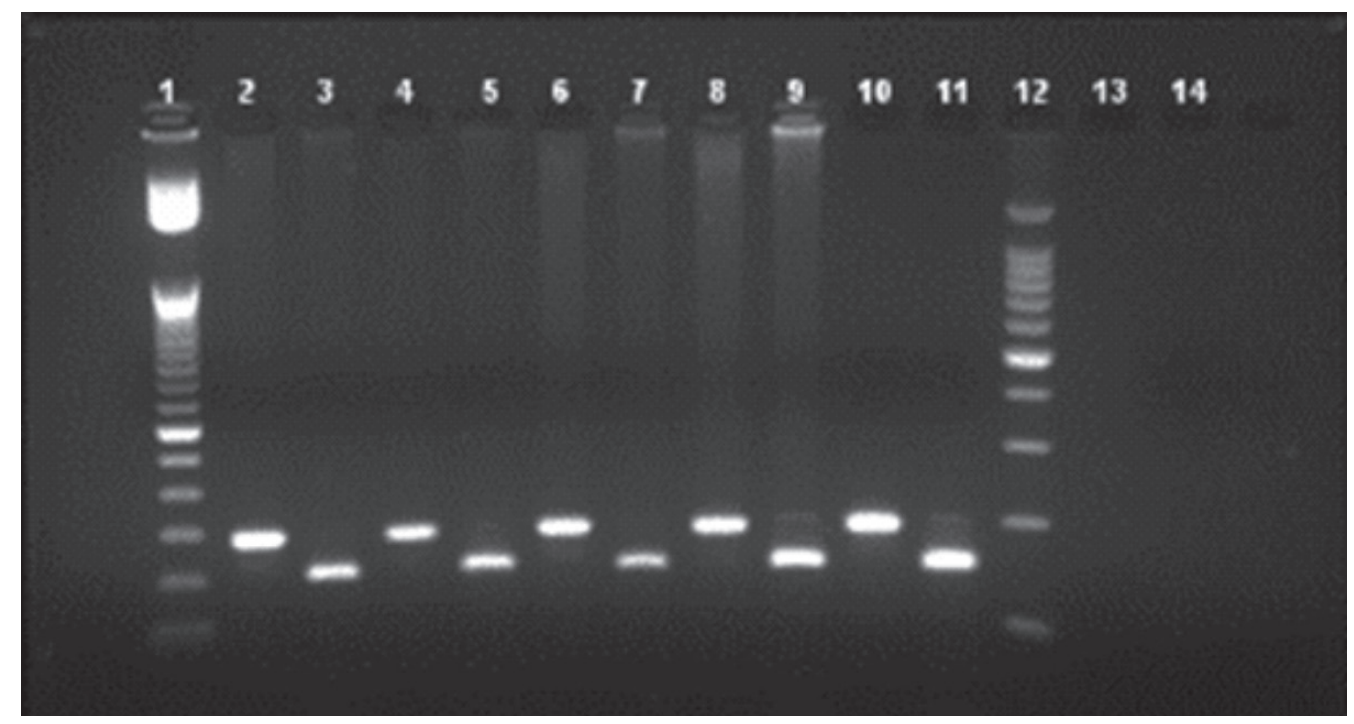

FIGURE 2 - Agarose gel analysis of the 14676 region RFLP-PCR SmlI-digested and undigested fragments. PCR products from the 14676 region of Mycobacterium leprae were digested $10 \mathrm{U} / \mu \mathrm{L}$ of $S m l \mathrm{I}$ for 1 hour. The digested products were run on a 3\% agarose gel for 1.5 hour at 80 volts. Lane 1: 50bp DNA ladder; Lanes 2, 4, 6, 8, and 10: undigested 194bp fragments; Lanes 3, 5, 7, 9, and 11: 149bp digested fragments; Lane 12: 100bp DNA ladder; Lane 13: undigested negative control; Lane 14: digested negative control. RFLP-PCR: restriction fragment Length polymorphism-polymerase chain reaction; $\boldsymbol{S m I I}$ : endonuclease I from Stenotrophomonas maltophilia; bp: base pair; DNA: deoxyribonucleic acid.

TABLE 2

Cycle threshold average, standard deviation, and copy number range of Mycobacterium leprae in environmental water samples from Boa Viagem, Crato, Mulungu, Juazeiro do Norte and Sobral, 2010-2013.

\begin{tabular}{lccc}
\hline Municipality & Average $\mathbf{C}_{\mathbf{t}}{ }^{*}$ & Standard deviation & Copy range $\left(\mathbf{C}_{\mathbf{t}} \leq \mathbf{3 7}\right)$ \\
\hline Mulungu & 29.55 & 2.18 & $1.88 \times 10^{1}-1.42 \times 10^{-1}$ \\
Crato & 29.48 & 2.91 & $9.11 \times 10^{1}-3.95 \times 10^{-1}$ \\
Juazeiro do Norte & 28.96 & 0.71 & $1.66 \times 10^{1}-3.85 \times 10$ \\
Sobral & 28.83 & 1.31 & $3.23 \times 10^{1}-1.81 \times 10$ \\
Boa Viagem & 27.41 & 1.11 & $1.44 \times 10^{2}-4.27 \times 10$ \\
\hline
\end{tabular}

$\mathrm{C}_{\mathrm{t}}$ : cycle threshold. $* \mathrm{p}=0.0005$.

TABLE 3

Poisson regression model exploring the association between the Mycobacterium leprae genotypes identified in CDERM patient biopsies and environmental waters of the municipality of Juazeiro do Norte, Brazil, 2010-2013.

\begin{tabular}{|c|c|c|c|c|c|c|c|c|c|c|}
\hline & \multirow{2}{*}{\multicolumn{2}{|c|}{ Negative }} & \multirow{2}{*}{\multicolumn{2}{|c|}{ Positive }} & \multicolumn{3}{|c|}{ Crude analysis } & \multicolumn{3}{|c|}{ Adjusted analysis } \\
\hline & & & & & \multirow[t]{2}{*}{ IRR } & \multirow[t]{2}{*}{$95 \%$ CI } & \multirow[t]{2}{*}{$\mathbf{p}$} & \multirow[t]{2}{*}{ IRR } & \multirow[t]{2}{*}{$95 \% \mathrm{CI}$} & \multirow[t]{2}{*}{$\mathbf{p}$} \\
\hline & $\mathbf{n}$ & $\%$ & n & $\%$ & & & & & & \\
\hline water & 32 & 66.7 & 16 & 33.3 & 1 & & & 1 & & \\
\hline biopsy & 50 & 66.7 & 25 & 33.3 & 1.6 & $(1.1-2.2)$ & 0.016 & 1.6 & $(1.1-2.2)$ & 0.016 \\
\hline \multicolumn{11}{|l|}{ Genotyping } \\
\hline SNP 1 or 2 & 35 & 85.4 & 6 & 14.6 & 1.0 & $(0.8-1.2)$ & 1,000 & 1.0 & $(0.6-1.5)$ & 1,000 \\
\hline SNP 3 & 38 & 92.7 & 3 & 7.3 & 1.0 & $(0.8-1.2)$ & 1,000 & 1.0 & $(0.6-1.5)$ & 1,000 \\
\hline
\end{tabular}

CDERM: Dona Libânia National Reference Centre for Sanitary Dermatology; IRR: incidence rate ratio; CI: confidence interval; SNP: single-nucleotide polymorphism. 
A correlation was found between M. leprae DNA positivity in the water samples and the leprosy CDR of the municipality. Thus, the frequency of positivity obtained in Crato, Juazeiro do Norte, and Sobral could be associated with the high number of new cases detected annually in these cities, which are considered hyperendemic regions for leprosy. The high number of leprosy cases would be responsible for the excretion of the bacteria in the environment. The population of these municipalities, which most likely includes leprosy cases, makes use of the water reservoirs examined in this study for washing clothes, bathing, leisure activities, as well as direct consumption. Contamination of the water with $M$. leprae bacilli could be responsible for the continued transmission of the disease and would explain the high positivity values of these collection points. However, the Cities of Boa Viagem and Mulungu, which report few or no cases of the disease, are among the three municipalities (Mulungu 73.3\%, Juazeiro do Norte 64\%, and Boa Viagem $55.9 \%$ ) with a higher frequency of DNA positivity. These results may also indicate a possible impoverishment of the local health systems or a very low rate of notification of leprosy cases in these municipalities. Mulungu and Boa Viagem have a low population density (estimated population of 11,485 and 52,498 inhabitants, respectively, in $2010^{18}$ ); these cities have deficient health services dependent on other developed cities. Historically, the official incidence of leprosy in Mulungu and Boa Viagem has been much lower than in other municipalities in Ceará. These cities have a poor disease notification system and are surrounded by other cities with a high reported prevalence of leprosy ${ }^{4,19}$. Our results suggest that there are unnotified cases of leprosy in these cities and these untreated cases release bacilli that might contaminate the water reservoirs.

A previous study conducted in Ceará ${ }^{20}$ did not identify any differences between the anti-phenolic glycolipid-I (PGL-1) in seroprevalence among contacts of leprosy cases in Sobral and those with no known contacts in Mulungu. Therefore, the high seroprevalence frequency in Sobral and Mulungu might be explained by the presence of $M$. leprae in their environmental waters. Indirect contact with $M$. leprae harbored in environmental sources by individuals who had not been in contact with leprosy cases would lead to a specific immune response against the bacilli ${ }^{21}$.

A number of previous studies conducted in Ceará have demonstrated a diverse distribution of leprosy in the state ${ }^{4,22}$; the cities with a high disease incidence are in the most developed and urbanized regions, but have a high level of social inequality. Moreover, factors, such as limited education, social inequality, poor personal hygiene, and nutritional deficiency, have been reported to be associated with the development of leprosy. In addition, a possible influence of environmental variables on the increased risk of developing leprosy has been identified ${ }^{9}$. Another study conducted in Ceará has reported a significant association between bathing in environmental water sources 10 years prior to the emergence of the disease and the high number of leprosy cases in regions near water sources used for the purpose of bathing and washing clothes ${ }^{5}$. However, it is important to note that the detection of M. leprae DNA does not indicate that the bacilli in the analyzed environmental water samples are viable. The detected DNA may originate from live or dead bacteria, or even constitute extracellular DNA ${ }^{23}$; detection of bacterial DNA derived from lysis by heating followed by ultraviolet exposure has been demonstrated ${ }^{24,25}$.

The high proportion of biopsies and environmental samples with SNP type 4 originated from Western Africa during the slave trade period. Approximately four million slaves were brought to Brazil between the $17^{\text {th }}$ and $19^{\text {th }}$ centuries ${ }^{26}$ and leprosy disease was widespread among the slaves. In the state of Ceará, slave labor from Western Africa was used by sugarcane plantations, which was the main activity during the colonial period, as already demonstrated in other genotyping studies ${ }^{1,27}$. Thus, the predominance of SNP type 4 in Ceará is directly related to the Western African slaves. Similar to previous studies conducted in an endemic village in India, we found a concordance between the SNP subtyping (subtype 4-N) of M. leprae from skin biopsies and those from water samples, ${ }^{9,28}$.

Although TaqMan is described as a more sensitive and specific method compared to SYBR Green ${ }^{29-31}$, our assays using the SYBR Green dye were highly specific and sensitive because our primers were specific to $M$. leprae bacilli. Furthermore, SYBR Green is simple and low-cost method. Therefore, qPCR primer design and optimization were important for the success of the SYBR Green qPCR assay.

In addition, results with statistical significance were not obtained in our study because of the small number of genotyped clinical and environmental samples. The reason for this is the difficulty to amplify DNA from environmental samples, possibly due to the presence of inhibitory substances ${ }^{32}$. Future studies employing whole genome sequencing comparing biopsies of cases that live near the environmental water would address the role of water reservoirs in the transmission of this disease.

Detection of $M$. leprae DNA in environmental water samples and the genotypic concordance with strains from leprosy cases suggests indirect infection via waters containing leprosy bacilli. Therefore, we suggest that environmental waters containing the bacilli play a major role in the transmission of leprosy in the studied regions of the State of Ceará. These data could explain the PGL-1 seropositivity in people residing in municipalities without disease notification and may explain the diagnosis of new leprosy cases without previous contact with a patient. Our results also indicate that the individuals living nearby or have access to these waters containing the M. leprae bacilli should be monitored for early leprosy diagnosis. Improvements in living conditions in these areas should be implement and evaluated for the leprosy prevalence reduction. Further studies are necessary to investigate the role of the environment in the transmission dynamics of leprosy, including detection of M. leprae mRNA and the role of amoeba, fish and water plants that might harbor the bacteria and provide its viability.

\section{Acknowledgments}

We wish to thank the participants, as well all the support of the Center of Dermatology Dona Libânia in Fortaleza, Ceará.

\section{Financial support}

Conselho Nacional de Desenvolvimento Cientifico e Tecnológico Project Numbers 410573/2006-0 and 577028/2008-1.

\section{Conflicts of interest}

The authors declare that there is no conflict of interest. 


\section{REFERENCES}

1. Monot M, Honoré N, Garnier T, Araoz R, Coppée JY, Lacroix C, et al. On the origin of leprosy. Science 2005;308(5724):1040-2.

2. World Health Organization (WHO). Global Leprosy Strategy 2016-2020. Acelerating towards a leprosy-free world [Internet]. Geneve: WHO. 2016. 20 p. Available from: http://www.searo.who. int/entity/global_leprosy_programme/documents/global_leprosy_ strategy_2020/en/

3. World Health Organization (WHO). Global leprosy update, 2014: need for early case detection [Internet]. Weekl Epidemiol Record (WER). 2015;90:461-476. [cited 12 May 2016]. Available from: http://www.who.int/wer/2015/wer9036/en/.

4. Ministério da Saúde. Secretaria de Vigilância em Saúde. Boletim Epidemiológico Hanseníase. Aspectos Epiedemiológicos [Internet]. Coordenadoria de Promoção e Proteção à Saúde| Núcleo de Vigilância Epidemiológica. Secretaria da Saúde do Estado do Ceará; 2016 [cited 10/04/2016]. Available from: http://www.saude.ce.gov.br/index.php/ boletins?download=813\%3Ahanseniase-janeiro-de- 2012 .

5. Kerr-Pontes LR, Barreto ML, Evangelista CM, Rodrigues LC, Heukelbach J, Feldmeier H. Socioeconomic, environmental, and behavioural risk factors for leprosy in North-east Brazil: results of a case-control study. Int J Epidemiol. 2006;35(4):994-1000.

6. Truman R, Fine PE. 'Environmental' sources of Mycobacterium leprae: issues and evidence. Lepr Rev. 2010;81(2):89-95.

7. Desikan KV, Sreevatsa's scientifica contributions. Extended studies on the viability of Mycobacterium leprae outside the human body. Lepr Rev. 1995;66(4):287-95.

8. Matsuoka M, Izumi S, Budiawan T, Nakata N, Saeki K. Mycobacterium leprae DNA in daily using water as a possible source of leprosy infection. Indian J Lepr. 1999;71(1):61-7.

9. Turankar RP, Lavania M, Singh M, Siva Sai KS, Jadhav RS. Dynamics of Mycobacterium leprae transmission in environmental context: deciphering the role of environment as a potential reservoir. Infect Genet Evol. 2012;12(1):121-6.

10. Lavania M, Katoch K, Katoch VM, Gupta AK, Chauhan DS, Sharma R, et al. Detection of viable Mycobacterium leprae in soil samples: insights into possible sources of transmission of leprosy. Infect Genet Evol. 2008;8(5):627-31.

11. Wheat WH, Casali AL, Thomas V, Spencer JS, Lahiri R, Williams $\mathrm{DL}$, et al. Long-term survival and virulence of Mycobacterium leprae in amoebal cysts. PLoS Negl Trop Dis. 2014;8(12):e3405.

12. Secretaria da Saúde do Estado do Ceará. Informe Epidemiológico Hanseníase [Internet]. Governo do Estado do Ceará; 2013. Available from: http://www.saude.ce.gov.br/index.php/boletins.

13. Monot M, Honoré N, Garnier T, Zidane N, Sherafi D, PanizMondolfi A, et al. Comparative genomic and phylogeographic analysis of Mycobacterium leprae. Nat Genet. 2009;41(12):1282-9.

14. Fontes AN, Sakamuri RM, Baptista IM, Ura S, Moraes MO, Martinez AN, et al. Genetic diversity of Mycobacterium leprae isolates from Brazilian leprosy patients. Lepr Rev. 2009;80(3):302-15.

15. Wahyuni RA, Adriaty D, Iswahyudi I, Prakoeswa CRS, Agusni I, Izumi S. Mycobacterium leprae in Daily Water Resources of Inhabitants Who Live in Leprosy Endemic Area of East Java. Indonesian Journal of Tropical and Infectious Disease (IJTID). 2010;1(2):65-8.

16. Lavania M, Katoch K, Sachan P, Dubey A, Kapoor S, Kashyap M, et al. Detection of Mycobacterium leprae DNA from soil samples by PCR targeting RLEP sequences. J Commun Dis. 2006;38(3):269-73.
17. Frota CC, Lima LN, Rocha Ada S, Suffys PN, Rolim BN, Rodrigues LC, et al. Mycobacterium leprae in six-banded (Euphractus sexcinctus) and nine-banded armadillos (Dasypus novemcinctus) in Northeast Brazil. Mem Inst Oswaldo Cruz. 2012;107(Suppl 1):20913.

18. Instituto Brasileiro de Geografia e Estatística, Brasil. - IBGE - Cidades@ 2016. [Internet]. Ministério do Planejamento, Desenvolvimento e Gestão. Available from: http://cidades.ibge.gov. $\mathrm{br} / \mathrm{xtras} / \mathrm{uf}$. php?lang=\& coduf $=23 \&$ search $=$ ceara.

19. Secretaria da Saúde do Estado do Ceará. Informe Epidemiológico Hanseníase [Internet]. Governo do Estado do Ceará; 2014. Available from: http://www.saude.ce.gov.br/index.php/boletins.

20. Frota CC, Freitas MV, Foss NT, Lima LN, Rodrigues LC, Barreto ML, et al. Seropositivity to anti-phenolic glycolipid-I in leprosy cases, contacts and no known contacts of leprosy in an endemic and a non-endemic area in northeast Brazil. Trans R Soc Trop Med Hyg. 2010;104(7):490-5.

21. Primm TP, Lucero CA, Falkinham 3rd JO. Health impacts of environmental mycobacteria. Clin Microbiol Rev. 2004;17(1): 98-106.

22. Kerr-Pontes LR, Montenegro AC, Barreto ML, Werneck GL, Feldmeier H. Inequality and leprosy in Northeast Brazil: an ecological study. Int J Epidemiol. 2004;33(2):262-9.

23. Miskin IP, Farrimond P, Head IM. Identification of novel bacterial lineages as active members of microbial populations in a freshwater sediment using a rapid RNA extraction procedure and RT-PCR. Microbiology. 1999;145(Pt 8):1977-87.

24. Sheridan GE, Masters CI, Shallcross JA, MacKey BM. Detection of mRNA by reverse transcription-PCR as an indicator of viability in Escherichia coli cells. Appl Environ Microbiol 1998;64(4):1313-8.

25. Birch L, Dawson CE, Cornett JH, Keer JT. A comparison of nucleic acid amplification techniques for the assessment of bacterial viability. Lett Appl Microbiol. 2001;33(4):296-301.

26. Taylor KS. The Economics of Sugar and Slavery in Northeastern Brazil. Agricultural History. 1970;44(3):267-280.

27. Fontes AN, Gomes HM, Araujo MI, Albuquerque EC, Baptista IM, Moura MM, et al. Genotyping of Mycobacterium leprae present on Ziehl-Neelsen-stained microscopic slides and in skin biopsy samples from leprosy patients in different geographic regions of Brazil. Mem Inst Oswaldo Cruz. 2012;107(Suppl 1):143-9.

28. Turankar RP, Lavania M, Chaitanya VS, Sengupta U, Darlong J, Darlong F, et al. Single nucleotide polymorphism-based molecular typing of M. leprae from multicase families of leprosy patients and their surroundings to understand the transmission of leprosy. Clin Microbiol Infect. 2014;20(3):O142-9.

29. Heid CA, Stevens J, Livak KJ, Williams PM. Real time quantitative PCR. Genome Res. 1996;6(10):986-94.

30. Dinoop KP, Parija SC, Mandal J, Swaminathan RP, Narayanan P. Comparison of nested-multiplex, Taqman \& SYBR Green real-time PCR in diagnosis of amoebic liver abscess in a tertiary health care institute in India. Indian J Med Res. 2016;143(1):49-56.

31. Soltany-Rezaee-Rad M, Sepehrizadeh Z, Mottaghi-Dastjerdi N, Yazdi MT, Seyatesh N. Comparison of SYBR Green and TaqMan real-time PCR methods for quantitative detection of residual $\mathrm{CHO}$ host-cell DNA in biopharmaceuticals. Biologicals. 2015;43(2):130-5.

32. Schrader C, Schielke A, Ellerbroek L, Johne R. PCR inhibitors occurrence, properties and removal. J Appl Microbiol. 2012;113(5): 1014-26. 